\title{
Model of Capacity Building for Civil Servants Through Integrative Education and Training (Case Study: In The Yogyakarta Provincial Education and Training Agency)

\author{
Fitriana, K.N. ${ }^{1}$, Satlita, L. ${ }^{2}$, Winarni, F. ${ }^{3}$ \\ ${ }^{123}$ Department of Public Administration, Faculty of Social Sciences, Yogyakarta State University \\ kurnianurfitriana@uny.ac.id ${ }^{1}$, lensa@uny.ac.id², francisca_winarni@uny.ac.id
}

\begin{abstract}
The paper is a working paper as dissemination of preliminary research findings aimed at explaining the human resource development model through the implementation of integrative education and training at the Yogyakarta Provincial Education and Training Agency. The development of civil servants was still carried out conventionally in the form of tutorials in the classroom, intensive guidance, and offline learning processes. This has an impact on achieving non-optimal participant outcomes and long-term stagnation in developing the professional capacity of civil servants. The research method uses research and development through qualitative analysis techniques with the steps: (1) identification of potential and problems, (2) data collection, (3) designing a model, (4) model validation, (5) model revision, (6) ) limited product trials, (7) product revisions, (8) trial use, (9) final revisions, and (10) dissemination. Data collection techniques through observation, interviews, focus group discussions, and documentation. Data analysis techniques used in this study are qualitative analysis techniques include data unit processing, data reduction, data categorization, checking data validity and data interpretation. Meanwhile, data validation in this research through triangulation techniques of research data sources and triangulation of data collection techniques. This research is oriented to produce an integrated model of civil servants development as the initial findings of the study because it is not yet at the stage of applying the model widely. The results showed that the model of human resource development through the implementation of integrated training and education for civil servants at the Yogyakarta Provincial Education and Training Agency had provided innovations in training material content integratively and according to the skills needs of participants. Training materials in capacity building for civil servants become more dynamic and focus on developing the capacity of individual civil servants inclusively. Hence, the participants have self-actualization in understanding the material and completing their tasks both offline and online. Contribution of this research can provide recommendations for the development model of human resource development for state civil society to relevant stakeholders.
\end{abstract}

Keywords: human resource management, capacity development models of civil servants, education and training.

\section{Introduction}

Civil servants are an important human resource asset for governance in the bureaucracy. The role of civil servants in the bureaucracy is very strategic in achieving organizational goals, providing public services, carrying out bureaucratic reforms, and contributing to development to face globalization. In terms of quantity, in the last five years, the number of civil servants in 
Indonesia and the regions have experienced dynamic changes by the analysis of the needs of civil servants nationally and regionally. There were 4,189,121 civil servants as of December 31, 2019, wherein 2015 to December 2018 the number of civil servants has decreased, this is due to the large number of civil servants who retire and the moratorium on civil servants for 2 (two) years, which is then followed by an increase in the number of civil servants in December 2019 amounted to $0.09 \%$ [1]. However, the dynamic number of civil servants is not followed by an even distribution of civil servants in each region.

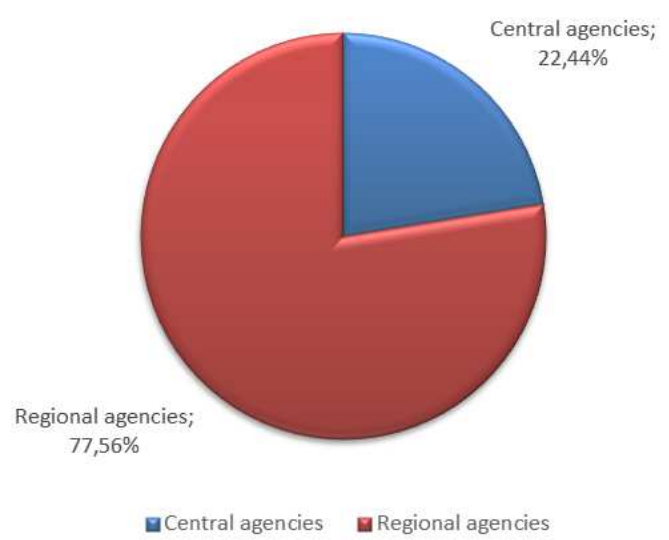

Fig.1. The total number of civil servants in Indonesia on 2018 Source: The State Agency of Civil Servants Affairs, 2019.

Based on data from The State Agency of Civil Servants Affairs for 2018, the total number of civil servants was $4,185,503$ people, with details of 939,236 civil servants or $22.44 \%$ serving in central agencies and 3,246,267 civil servants or $77.56 \%$ serving in regional agencies. Based on this data, the distribution of civil servants with the highest number is in Java with a percentage of $20.64 \%$ or equivalent to $1,209,036$. On the other hand, the lowest number of civil servants was in Papua and Maluku with a percentage of $5.83 \%$ amounting to 248,020 civil servants. Meanwhile, from the age distribution, the number of civil servants is dominated by the 41-60 year age group, reaching 2,896,821 people, while for the 18-40 year age group 1,288,682 people. In the aspect of formal education attainment, it can be seen that $52 \%$ of total civil servants occupy the level of education equivalent to undergraduate (S1) and the second-largest with a percentage of $21 \%$ at the level of Senior High School (SLTA). When viewed from the formation of civil servants, it can be seen that $71.19 \%$ is recorded as teaching staff, $14.15 \%$ are health workers, and $14.67 \%$ are technical personnel [2]. Furthermore, from the element of the position, statistical data shows $11.03 \%$ in structural positions, $37.18 \%$ in certain functional positions, and $51.59 \%$ in general functional positions The large potential of civil servants in governance must be managed optimally to contribute to good performance through human resource development. Law number 23 of 2014 concerning regional government states that concerning regional authority in developing civil servant resources it is carried out through career development by considering integrity, morality, education and training, rank, and competence. By having the competency of the position, the process of governance in the regions will be optimal because civil servants already know their respective duties and functions professionally. 
In the management of civil servants, the regional government also has the authority to develop and enhance its competence, namely through the management of civil servants in the regions through procedures starting with the establishment of formations, recruitment of employees, transfers and dismissals, rights, obligations in legal standing, competency development and employee control. The government, in realizing professional civil servants, issued Government Regulation number 101 of 2000 concerning education and training for civil servant positions to create professional civil servants. The duties of civil servants in the future must be able to carry out public services, carry out government duties and other development tasks. Competency development of civil servants is based on qualifications, competence and performance in the position (merit system) as human resource assets in the organization as many as 20 lesson hours per year. Basic training aims to develop the competence of prospective civil servants in an integrated manner. The competencies that must be possessed by civil servants include: (1) demonstrating the attitude of defending the state; (2) actualizing basic values in the implementation of their duties; (3) actualizing the position and role of civil servants within the framework of the Indonesian state; and (4) demonstrates mastery of the required technical competencies by the task field. The implementation of basic training for civil servant candidates combines: (1) classical and non-classical training; and (2) socio-cultural competence with field competence as a basis for consideration in improving the basic training program for civil servant candidates. Human resource development programs are efforts to improve quality and careers based on the competence of employees in an organization. Efforts to develop human resources are of course intended so that the organization can realize its vision in achieving the goals of the organization. On the other hand, for employees or employees, a human resource development program can be defined as a systematic learning and training process to improve their competence and performance in their current jobs and prepare themselves for future roles and responsibilities [3]. Efforts to improve the quality of human resources as a human resource development program must be carried out consistently and continuously.

Human resource competency development is an effective way to overcome some of the challenges faced by public organizations through efforts to improve the ability of employees to handle various types of assignments [4]. The goal of developing human resource competencies will be able to increase experience and competitive abilities as an effort to increase the ability of organizations to compete and adapt to changes in competitive environments. Meanwhile, specifically, the goal of developing the competence of civil servants is to improve the level of effectiveness of employee performance in achieving results according to performance targets through knowledge development, skills development, and attitude changes [5]. Thus, the development of the capacity of civil servants is to improve the quality of professionalism and skills of employees in carrying out their duties and functions optimally so that they can carry out their duties more effectively, efficiently and productively. Therefore, public organizations need to continue to develop the capacity of civil servants as an investment in human capital.

Human resource management for civil servants has been regulated in Law Number 5 of 2014 concerning State Civil Servants and Government Regulation No.11 of 2017 civil servants management, Government Regulation of the Republic of Indonesia Number 101 of 2000 concerning Education and Training for Employee Positions Civil Affairs, Education and Training is the process of organizing teaching and learning in order to improve the ability of Civil Servants. As well as the Regulation of the State Administration of the Republic of Indonesia No.12 of 2018 concerning basic training for civil servant candidates. Apparatus capacity development is the right for civil servants to gain useful expertise in supporting an 
organization as stipulated in article 22 of Law Number 5 of 2014 concerning the civil sevants. In this article, it is mandated that every civil servant has the right to be developed by the government, both central and local governments. The urgency of capacity building is inseparable from planning needs through development training and can be tailored to the needs of the organization to support organizational performance. Some of the most commonly used management development methods include: training methods; understudies; job rotation and planed progression; coach-counselling; junior boards of an executive or multiple management; committee assignment; staff meetings and projects; business games; sensitivity training; and other development methods [6].However, there are many problems in implementing capacity building for civil servants as background problems: (1) A paradigm shift in the management of civil servants; (2) The low motivation of civil servants in increasing professionalism; (3) The gap of regional authority in developing the capacity of civil servants; (4) The civil servants education and training model is still conventional; (5) The challenges of information technology in training in a disruptive era through the application of distance education and training; (6) Challenges of morality and corrupt behaviour by public servants; and (7) Challenges of Covid-19 pandemic. Hence, the research findings aimed at explaining the human resource development model through the implementation of integrative education and training at The Yogyakarta Provincial Education and Training Agency.

\section{Method}

The research method used research and development through qualitative analysis techniques. Data was collected through observation, in-depth interviews, focus group discussion, and documentation of secondary data. Analytical techniques are carried out qualitatively with research and development steps included: (1) identification of potentials and problems, (2) data collection, (3) designing model draft, (4) model validation, (5) review and revision model, (6) limited product trial, (7) product revision, (8) trial usage, (9) final revision, and (10) result dissemination. This research is oriented to produce an integrated model of civil servants development as the initial findings of the study because it is not yet at the stage of applying the model widely. This research was conducted at the Research Agency for 6 months from February to July 2020. Research informants are people who can provide information about the actual situation of the research object so that the data obtained in this study can be accurate. -Parties involved in the process of developing human resources in developing the human resources of the civil servants through integrated education and training include: (1) Head of the Yogyakarta Provincial Education and Training Agency; (2) Manager of integrated education and training for civil servants; (3) Lecturer / facilitator / mentor; (4) Participants of the integrated for civil servants. Therefore, this study examines more deeply the human resource development model through the implementation of integrative education and training at the Yogyakarta Provincial Education and Training Agency.

\section{Result And Discussion}

The stages of human resource development can be carried out through the following steps [7]: (1) Investigating both the external, internal and organizational environment;(2) Forecasting or forecasting the availability of supply and demand for current and future human 
resources; (3) Planning for recruitment, training and promotion; and (4) Utilization, which is aimed at manpower and then provides feedback for the initial process. Training is one type of learning process to acquire and improve skills outside the applicable education system in a relatively short time and with methods that prioritize practice rather than theory [8]. Training helps employees understand practical knowledge, in order to improve the skills, abilities, attitudes needed by the organization in an effort to achieve goals [9]. Meanwhile, education is an activity to improve the mastery of theory and skills in deciding on issues related to activities to achieve goals. Education is an activity to improve the ability of employees by increasing knowledge and understanding of general knowledge and economic knowledge in general, including increasing mastery of theory in dealing with organizational problems [10]. This effort is made to improve the productive contribution of employees and develop human resources to face all the possibilities that occur due to environmental changes. In principle education and job training are divided into two, namely pre-service education and training and in-service education and training: (1) pre-service training is a training given to prospective civil servants; (2) education and in-service training is a training aimed at improving the quality, expertise, abilities and skills.

This model describes the governance of the implementation of integrated education and training for the development of the capacity of civil servants which consists of 4 fundamental aspects: (1) smart learning and training infrastructure; (2) learning management and assessment centre; (3) integrative education and learning delivery system; (4) output; and (5) outcome. In the aspect of smart learning and training infrastructure, it must be supported by the capacity of virtual learning and training environments, educational platforms, adaptive and agile policy. Aspects of learning management and assessment centre consist of learning management support systems, interactive and responsive management both online and offline, complaint system management. Meanwhile, aspects of the integrative education and learning delivery system as governance in the implementation of education and training include the internship program skills in civil servants institutions, flipped classrooms, interactive online content, and e-learning. The final aspect is the output and outcome. The output is the training result product that has been produced by the training participants in the form of a portfolio of reports, assignment, and exam results. Meanwhile, the outcome is the impact of the application of attitudes and results by civil servants to become professional, accountable, and have a good moral attitude.

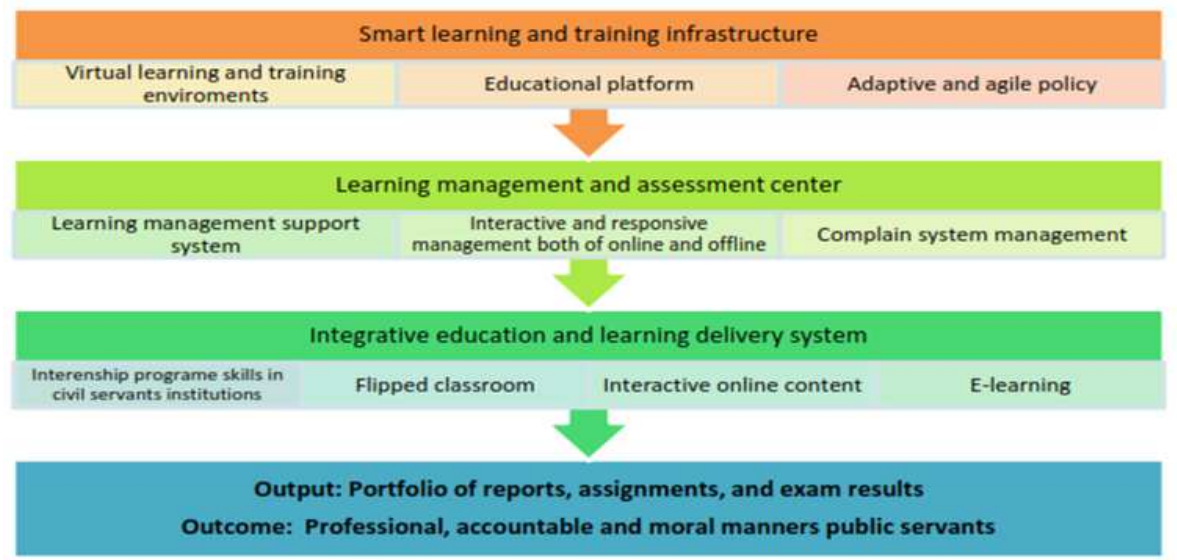

Figure 2. The integrative education and learning model for the civil servants capacity building Source: Authors, 2020. 
The final results of the application of this model have implications for developing the capacity of civil servants after completing the training as follows: (1) improving leadership skills, innovative skills, managerial skills and soft skills for civil servants; (2) building trust, mindset and sense of belonging among stakeholders; (3) developing professional, accountable and moral manners public servants; (4) adopting local values and publicness values in learning and training materials; (5) integrating adaptive and agile mainstreams into the education curriculum and empowering program for civil servants.

\section{Conclusion}

The results showed that the model of human resource development through the implementation of integrated training and education for civil servants at the Yogyakarta Provincial Education and Training Agency had provided innovations in training material content integratively and according to the skills needs of participants. Training materials in capacity building for civil servants become more dynamic and focus on developing the capacity of individual civil servants inclusively. Hence, the participants have selfactualization in understanding the material and completing their tasks both offline and online. Contribution of this research can provide recommendations for the development model of human resource development for state civil society to relevant stakeholders.

\section{References}

[1] The State Agency of Civil Servants Affairs, Buku Statistik ASN. Jakarta: The State Agency of Civil Servants Affairs,

[2] https://www.bkn.go.id/wp-content /uploads/2019/04/Statistik-PNS-per-December-2018-TenagaGuru-dan-K Health-Menjadi-Fokus-Pemenuhan-K needs-ASN.pdf, 2019.

[3] A. S. Ruky, Sumber Daya Manusia Berkualitas. Jakarta :PT.Gramedia Pustaka Utama, 2006.

[4] Moekijat, Manajemen personalia dan sumber daya manusia. Bandung: Mandar Maju, 2020.

[5] R. Mathis And J. H. Jackson, Manajemen Sumber Daya Manusia. Jakarta: Salemba Empat PT Salemba Emban Patria, 2002.

[6] M. Manullang, Manajemen Sumber Daya Manusia. Yogakarta: BPFE, 2001.

[7] E. Sutrisno, Manajemen Sumber Daya Manusia. Jakarta : Kencana, 2011.

[8] T. Y. Suwatno, Manajemen Sumber Daya Manusia. Teori, Aplikasi dan Penelitian Bandung: PPs dan CV Alffabeta, 2009.

[9] J. Suprihanto, Penilaian kinerja dan pengembangan pegawai. Yogyakarta: BPFE, 2001.

[10] A. T. Sulistiyani and Rosidah, Manajemen Sumber Daya Manusia : Konsep, Teori Dan Pengembangan Dalam Konteks Organisasi Publik. Yogyakarta : Graha Ilmu, 2003. 